\title{
Nasi Minyak, A Product Of Arabian Culinary Heritage, As A Gastronomy Tourism In Palembang City
}

\author{
Yuyun Febriyanti \\ Ambarrukmo Tourism Institute, Jl. Ring Road Timur No 25, Pelem Mulong, Banguntapan, \\ Bantul, Daerah Istimewa Yogyakarta 55198
}

*Corresponding Author E-mail: Yuyunfebriyanti1199@gmail.com

\begin{abstract}
Gastronomy tourism is a food tasting activity that does not only focuses on food but also emphasizes cultural aspects as well as studies the history of the food itself. Indonesian gastronomy is believed to be formed from a fusion of culture and food between natives, such as Chinese, Indians, Middle East, Europe, Portuguese and Dutch. Palembang is a city that is rich in culture from customs to cuisine. Palembang is influenced by various cultures such as Chinese, Middle East, and Arabic. One of Palembang's culinary that is influenced by Arabic culture is nasi minyak (Indonesian fragrant spiced rice). The method used in this research is descriptive qualitative. While the data processing technique is done by observation and interview techniques. The results show that nasi minyak is similar to the original Arabian kabsa rice, introduced by Arab descendants namely Al-Munawar community, when they threw a party. However, they served the cuisine by adapting the taste to the Palembang people's. The ingredients used to make rice oil are white rice, ginger oil, onions, garlic, coriander, cumin, cinnamon, star anise, cloves, cardamom, lemongrass, broth, nutmeg, sweet fennel, ginger, bay leaf, milk, tomato/tomato sauce, and turmeric.
\end{abstract}

Keywords: Gastronomy Tourism; Palembang; Nasi Minyak; Arabian Culinary Heritage.

\section{First Received: August 2020}

Final Proof Received: September 2020

\author{
Revised: \\ August 2020
}

Accepted:

September 2020

Published:

December 2020 


\section{Introduction}

Indonesia has a variety of tourist attractions, such as natural, cultural, and artificial or special interest. The tourism industry in terms of culture, indirectly provides an important role for the development of Indonesian culture because with the existence of a tourist attraction it can introduce the cultural diversity of a country such as traditional arts, religious ceremonies or eating culture that attracts the attention of foreign tourists and Indonesian tourists. With this diversity, Indonesia continues to improve the development of tourism for each Province by with its local potential. The development of the tourism industry can provide opportunities for tourism products including culinary in Palembang. The high development of the tourism industry provides a huge opportunity for the community to participate in the development of culinary tourism which is currently still limited in number.

In the context of developing food-based tourism, the concept of culinary tourism becomes a major part. Culinary tourism can be interpreted as an activity while eating somewhere. Meanwhile, food activities that not only discuss food but also about the cultural and historical fields of the food itself, it can be requested as a gastronomy tourism. Indonesian gastronomy combines the formation of a fusion of culture and food between natives, Chinese, Indians, the Middle East, and Europe, such as the Portuguese and the Dutch. Culinary is part of the contribution of cultural development that gives strength to destinations, including in Palembang.

Palembang is a city that is rich in culture from customs to cuisine. Palembang's cuisine is salty, sour, spicy, and rich in spices compared to culinary from other big cities such as culinary in Java. Some of the popular culinary in Palembang are pempek, pindang, maksuba, kojo, and nasi minyak. Palembang culinary has clear soups like pindang and tekwan, model and some are rich in spices such as curry, laksan, burgo, celimpungan, and others.

Palembang, as a city in Indonesia, is a gathering place for residents of various cultures that have diverse communities such as Chinese, Indian, and Arabic. Palembang cuisine is influenced by Chinese cultures such as pempek, model, tekwan, laksan, celimpungan, and many more. Palembang's cuisine is influenced by Indian and Arabic cultures such as Mmartabak Hhar, nasi minyak, goat curry, and chicken curry.

Nasi minyak has a savory taste typical middle eastern spices with a strong aroma of spices. nasi minyak is usually served on certain occasions, such as weddings, thanksgiving, Eid al-Fitr, Eid al-Adha, and as a special dish in Ramadan. nasi minyak is like the original Arabic kabsa rice. It was introduced by Arab descendants namely Al-Munawar community, when they threw a party. However, they served the cuisine by adapting the taste to the Palembang people's. The purpose of this study is to identify how the influence of Arabic culture on nasi minyak as one of gastronomy tourisms in Palembang.

\section{Literature Review}

\subsection{Culinary}

Culinary tourism is broadly defined as a destination for unique and memorable food and beverage experiences, providing a way to connect the local food system with the tourist experience (Green \& Dougherty, 2008).

Culinary tourism is related to local food from the tourist destination. Local food is indispensable in the tourist experience when it can present both cultural and entertainment activities (Rahma et al., 2017)

Culinary tourism is one form of cultural tourisms, for cuisine is an integral part of the culture of all communities, It does not refer only to particular community's or culture's food but its whole "food culture" (including cooking and dining) may become the basis of narratives, rituals, festivals or other aspects of cultural 
expression. Thus, culinary tourism means more than merely consuming food on a trip: it also means the direct experience of a given area's unique culinary culture and "local knowledge" (Ignatov \& Smith, 2006)

\subsection{Gastronomy tourism}

Gastronomy tourism is an emerging phenomenon attracting millions of tourists who are motivated to travel by activities related to food experiences; the quality, variety and uniqueness of local products; and the opportunity to experience exclusive events (Kivela \& Crotts, 2006)

Gastronomy is about the recognition of the variety of factors relevant to the food and beverages ate and consumed by a group in a locality, region, or even nation. Another understanding of gastronomy is the relationship between culture and food in studying the cultural component with food as its center (culinary arts). (Uğurlu, 2016)

Gastronomy coverage does not only look at food in terms of cultural understanding and assets for the region (Nurwitasari, 2016)

\section{Materials and Methods}

\subsection{Location}

The location of the study was conducted in the Kampung Arab Palembang.

\subsection{Method}

The method used in this research is descriptive qualitative, namely the approach to human groups, an object, a condition, or a thought. The aim is to describe a condition in a systematic and actual and accurate manner regarding a phenomenon (Nazir, 2005).

\subsection{Data Collection Techniques}

Observation is an activity to search, record, formulate, and analyze to compile the report. Random interviews were conducted with the people of Palembang who also made and consumed nasi minyak. Interviews were conducted to strengthen field data of nasi minyak in terms of cultural and historical values. So that it can answer how the influence of Arabic culture on nasi minyak can be a gastronomy tourism in Palembang

\section{Results and Discussion}

\subsection{History}

In history, Palembang recorded as a place for international trade, including Arabs and Chinese. Its location as a very strategic trade axis makes Palembang visited by many traders and spreaders of Islamic symbols from the Arabian peninsula. Initially, migrants who were intermediary traders were not allowed to live on land, so they lived on the edge. Along with the rapid development of the economy, they were given the freedom to live on the banks of the Musi river in the Ulu section of Palembang which is now known as Kampung Arab Al-Munawar. The majority of the residents of Al-Munawar village are of typical Arab descent. Physiologically, the man has a tall body, a sharp nose, thick eyelashes, and chest hair. Whereas the woman has a beautiful face and a sharp nose.

Their residence in the land of Palembang brought the mission and culture of their home country, ranging from interaction to culinary. A strong kinship culture in the Arab descendants of Al-Munawar in the city of Palembang is suspected as one of the triggering factors of the transformation of Middle Eastern culinary into Palembang cuisine, in addition to the taste and aroma of spices which is strong and appetizing.

Transformation of Middle Eastern culinary to Palembang culinary can occur through activities or events carried out by Arab descendants of Al-Munawar, one of which is a wedding. At weddings they served food that had a distinctive taste similar to the spices of Arab countries, 
which are characterized by savory flavors and strong aromas of spices such as kabsa, meat curry, selado, sambal, and pickled pineapple.

Along with the development of cultures that entered Palembang, the Arabic culture was adopted by the local community, for example weddings. Palembang's wedding ceremony nowadays usually serves staple foods namely samin rice/nasi minyak with complementary foods such as malbi meat, soy chicken/ curry chicken, potato sauce, gado-gado, pickles, pineapple sauce and etc.

\subsection{Nasi minyak}

Nasi minyak is a culinary result of assimilation between Palembang's local Malay culture and the Arab immigrants'. In the past nasi minyak was a special food that was only served to the Palembang Darussalam Sultanate family environment only. Nasi minyak was a routine dish for the Sultan of Palembang every Friday after he performsed Friday prayers. Nasi minyak s was also often served to great guests who visit the Palembang Darussalam Sultanate. Today, nasi minyak has become a gastronomy tourism of Palembang and everyone can enjoy it.

Nasi minyak is rice similar to kabsa rice from Saudi Arabia. Nasi minyak made from Samin oil, onions, garlic, coriander, cumin, cinnamon, star anise, cloves, cardamom, lemongrass, powder broth, nutmeg, ginger, bay leaf, milk, tomatoes/sauce tomatoes, and turmeric. Whereas Kkabsa rice originates from Saudi Arabia using meat, tomato sauce, red chilies, bay leaves, lemongrass, cloves, cardamom, star anise, masala salt, and powder broth. Both of these cuisines use basmati rice except Palembang people replace it with white rice.

There are two types of nasi minyak namely red and yellow. The red color extracted from tomato additives while the yellow color extracted from turmeric, the same ingredients used in making kebuli rice.
4.3. How to make nasi minyak

a. Saute the seasoning that has been mashed, namely, onions, garlic, coriander, and ginger using samin oil until fragrant.

b. Then add cumin, cinnamon, star anise, cloves, cardamom, lemongrass, nutmeg, powdered broth, bay leaf, tomato/ tomato sauce for red rice, and turmeric for yellow rice. saute briefly until fragrant.

c. Add milk and rice. Bring the simmer until the rice is cooked.

d. After the rice is cooked, nasi minyak is ready to serve.

Table 1 Nutrision Food Ingredients

\begin{tabular}{|c|c|}
\hline Ingredients & Nutritions \\
\hline Onion & $\begin{array}{lr}\text { High in vitamins, } \\
\text { minerals, } \\
\text { antioxidant } \\
\text { compounds }\end{array}$ \\
\hline Garlic & $\begin{array}{l}\text { Vitamin C and B6, } \\
\text { contain active } \\
\text { ingredients alliin and } \\
\text { allicin }\end{array}$ \\
\hline Coriander & $\begin{array}{ll}\text { Vitamins } \mathrm{K}, \mathrm{A}, \mathrm{B}, \mathrm{E} \text {, } \\
\text { Minerals, } & \text { Essential } \\
\text { Compounds } & \end{array}$ \\
\hline Caraway & $\begin{array}{l}\text { Vitamins, Minerals, } \\
\text { Unsaturated fatty acids }\end{array}$ \\
\hline Cinnamon & $\begin{array}{l}\text { Calcium, fiber, and } \\
\text { many minerals like } \\
\text { manganese }\end{array}$ \\
\hline Star anise & $\begin{array}{l}\text { Vitamins A, B, C, D, } \\
\text { B-12, minerals, Fat }\end{array}$ \\
\hline Clove & $\begin{array}{l}\text { Calcium, magnesium, } \\
\text { and vitamin } \mathrm{E}\end{array}$ \\
\hline Cardamom & $\begin{array}{l}\text { essential oil, cineol, } \\
\text { terpineol, borneol, } \\
\text { sugar protein, and a } \\
\text { little fat }\end{array}$ \\
\hline Lemongrass & $\begin{array}{l}\text { Vitamins, minerals, } \\
\text { acids, fats }\end{array}$ \\
\hline Broth & $\begin{array}{l}\text { Fat, protein, } \\
\text { carbohydrate }\end{array}$ \\
\hline Nutmeg & $\begin{array}{l}\text { Vitamins } \mathrm{A}, \quad \mathrm{C} \text {, } \\
\text { Calcium, Fat, Iron, } \\
\text { Calcium, Protein }\end{array}$ \\
\hline
\end{tabular}




\begin{tabular}{|c|c|}
\hline Ingredients & Nutritions \\
\hline Anise & $\begin{array}{l}\text { Potassium, fiber, folic } \\
\text { acid and also vitamin } \\
\text { C }\end{array}$ \\
\hline Ginger & $\begin{array}{l}\text { Gingerol, magnesium, } \\
\text { vitamin C, vitamin B6, } \\
\text { phosphorus, copper, } \\
\text { iron, calcium, and zinc } \\
\text { in small amounts }\end{array}$ \\
\hline Bay leaf & $\begin{array}{l}\text { Antioxidants, } \\
\text { Vitamins, lauric acid, } \\
\text { Routine flavonoids, } \\
\text { salicylates, caffeic } \\
\begin{array}{l}\text { acid, and } \\
\text { phytonutrients }\end{array}\end{array}$ \\
\hline Milk & $\begin{array}{l}\text { calories, protein, fat, } \\
\text { calcium, vitamin D, } \\
\text { potassium, } \\
\text { phosphorus, selenium, } \\
\text { vitamin A, } \\
\text { magnesium, and B12 }\end{array}$ \\
\hline Rice & $\begin{array}{l}\text { Fat, } \\
\text { carbohydrate }\end{array}$ \\
\hline Tomato & $\begin{array}{l}\text { vitamins } \mathrm{A}, \mathrm{K}, \mathrm{B} 1, \mathrm{~B} 5 \text {, } \\
\mathrm{B} 3, \mathrm{~B} 6, \mathrm{~B} 7, \mathrm{C} \text {, and } \\
\text { minerals }\end{array}$ \\
\hline Turmeric & $\begin{array}{lr}\text { Fats, } & \text { carbohydrates, } \\
\text { proteins, } & \text { starches, } \\
\text { vitamins, } & \text { and } \\
\text { minerals. } & \end{array}$ \\
\hline
\end{tabular}

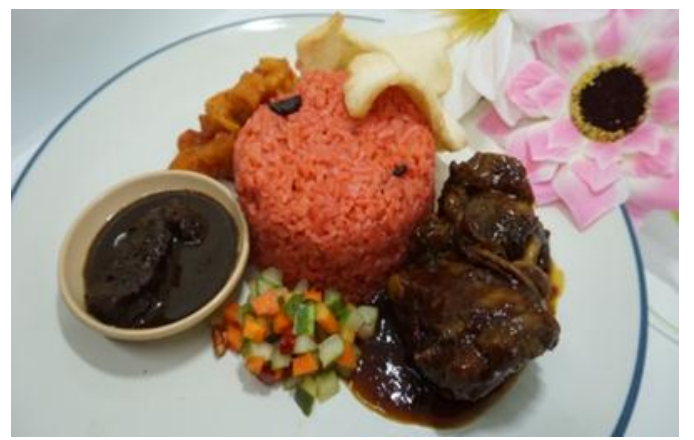

Figure 1. Nasi Minyak Merah

Figure 1 is an example of a nasi minyak merah supplemented with side dishes namely malbi meat, soy sauce chicken, potato sambel, pickles, and crackers. This food can be found in Dapur Ombai which sells typical Middle Eastern food.

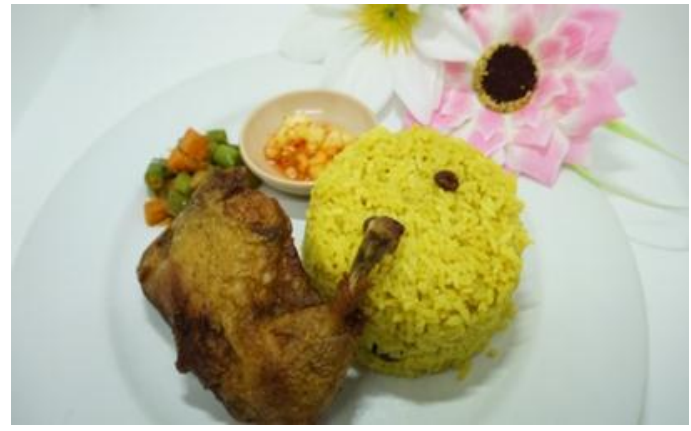

Figure 2. Nasi Minyak Kuning

In figure 2 is an example of nasi minyak kuning with fried chicken , vegetable beans, and also pineapple sambel as side dishes. This food can be found in Nasi Minyak Jamilla.

\section{Conclusions}

Based on the study it can be concluded that the nasi minyak originated from the cultural adaptation of Arabian cuisine introduced by Al-Munawar community, Arabian descendants, who initially only cooperated in trade and later settled in the Ulu area of Palembang. Due to the strong influence of Arabic culture in Palembang, the adaptation can be carried out quickly for instance at a wedding. In the past Nasi Minyak was a special food that was only served to the Palembang Darussalam Sultanate family environment only. Nasi minyak was a routine dish for the Sultan of Palembang every Friday after he performsed Friday prayers. Nasi minyak was also often served to great guests who visit the Palembang Darussalam Sultanate. Today, nasi minyak has become a gastronomy tourism of Palembang and everyone can enjoy it.

The menu presented by Arab descendants of Al-Munawar was kabsa rice, curry meat, selado, chili and pickled pineapple which used to add in basmati rice which was later adapted to the making of nasi minyak. Nasi minyak sellers are still small in number and usually sold at certain events only. To make nasi minyak better known to tourists is by increasing the marketing of Nasi Minyak as one of 
Palembang's culinary such as at culinary events or by motivating local communities to participate in selling nasi minyak so that the food is easy to obtain.

\section{References}

Green, G. P., \& Dougherty, M. L. (2008). Localizing linkages for food and tourism: Culinary tourism as a community development strategy. Community Development, 39(3), 148-158.

Guzel, Berrin \& Muge,Ap Aydin,. (2016). Gastronomy Tourism: Motivation and Destinatioans. Adnan Menderes University.Tourism Faculty.

Ignatov, E., \& Smith, S. (2006). Segmenting Canadian culinary tourists. Current issues in tourism, 9(3), 235.

Kivela, J., \& Crotts, J. C. (2006). Tourism and gastronomy: Gastronomy's influence on how tourists experience a destination. Journal of hospitality \& tourism research, 30(3), 354-377.

Nazir, M. (2005). Metode Penelitian. Bogor: Ghalia Indonesia

Nurwitasri, A. (2015). Pengaruh Wisata Gastronomi makanan tradisonal Sunda terhadap Keputusan Wisatwan Berkunjung ke Kota Bandung. BARISTA (Volume 2, Nomor 1, Juli 2015)

Rahma, Neila., Indah Susilowati, Evi Yulia Purwanti.2017. Minat Wisatawan terhadap Makanan Lokal Kota Semarang. (Tourists' Interest to Local Food In Semarang). Jurnal ekonomi dan pembangunan Indonesia.Vol. 18 No.1 Juli 2017:53-76 